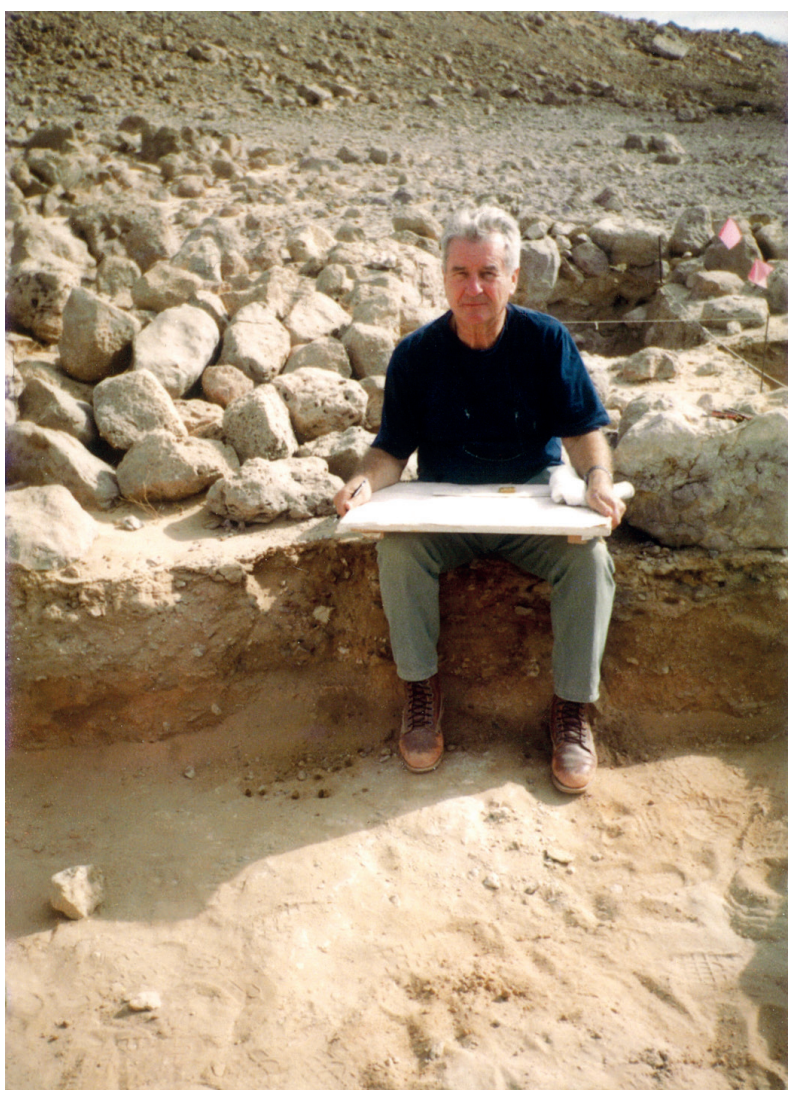

Wschodni Synaj, 1996 r.

Fot. Halina Królik

Prof. dr. hab. Romualdowi Schildowi $\mathrm{w}$ osiemdziesiątą piątą rocznicę urodzin i 62-lecie pracy naukowej 


\title{
PROFESOR DR HAB. ROMUALD SCHILD. KONTYNUACJA DZIAŁALNOŚCI NAUKOWEJ W LATACH 2008-2021
}

\begin{abstract}
Abstrakt: Profesor dr hab. Romuald Schild, badacz o ogromnym dorobku naukowym z zakresu prahistorii środkowej Europy i północno-wschodniej Afryki, były Dyrektor Instytutu Archeologii i Etnologii Polskiej Akademii Nauk, członek wielu organizacji międzynarodowych i polskich, obchodzi w $2021 \mathrm{r}$. osiemdziesiątą piątą rocznicę urodzin. Działalność naukową kontynuował także w ciągu ostatnich czternastu lat będąc już na emeryturze. W tym okresie brał czynny udział w badaniach terenowych w Polsce, a także kierował programem ratowania zabytków kultury neolitycznej z Pustyni Zachodniej w Egipcie. Wydał też trzy obszerne monografie polskich stanowisk dotyczących okresów paleolitu i mezolitu, kluczowych dla znajomości tych okresów.
\end{abstract}

Słowa kluczowe: Polska, Afryka, Romuald Schild, archeologia epoki kamienia Europy i Afryki

Abstract: An illustrious scholar in the field of the prehistory of Central Europe and North-eastern Africa, former Director of the Institute of Archaeology and Ethnology of the Polish Academy of Sciences, member of many international and Polish organizations, Professor Romuald Schild celebrates his eighty-fifth birthday in 2021. Since his retirement 14 years ago he has remained active in his field, actively participating in field research in Poland and leading a program for the protection of monuments of Neolithic culture from the Western Desert in Egypt. He has also published three comprehensive monographs of sites in Poland that are of crucial importance for the study of the Paleolithic and Mesolithic periods.

Keywords: Poland, Africa, Romuald Schild, archaeology of the Stone Age in Europe and Africa 
Profesor dr hab. Romuald Schild po szesnastu latach kierowania Instytutem Archeologii i Etnologii Polskiej Akademii Nauk przeszedł w 2007 r. na emeryturę. Przeszedł, ale w archeologii pozostał nadal czynny zawodowo przez kolejnych czternaście lat ${ }^{1}$.

Jak w całej swej dotychczasowej działalności naukowej, profesor Schild nadal kontynuuje badania w dwóch głównych zakresach - epoki kamienia w północno-wschodniej Afryce i epoki kamienia w środkowej Europie.

Swego rodzaju ukoronowaniem trwających blisko sześćdziesiąt lat badań prahistorii północno-wschodniej Afryki było przeniesienie w latach 2009-2010 z egipskiej Pustyni Zachodniej do Muzeum Nubijskiego w Asuanie monumentów kamiennych z późnoneolitycznego centrum ceremonialnego z Nabta Playa. Centrum to było przez kilkanaście lat badane przez polsko-amerykańską ekspedycję nazwaną Combined Prehistoric Expedition, której profesor Schild w ostatnich latach przed emeryturą był dyrektorem. Na cały ten rozległy neolityczny kompleks składały się kamienne megality i szereg pionowych steli skierowanych na północ magnetyczną i na gwiazdę Oriona. W skład jego wchodził też tak zwany kalendarz, czy raczej obserwatorium astronomiczne sprzed czterech tysięcy lat, także zbudowane z kamiennych głazów. Z dużym prawdopodobieństwem stwierdzić można, że twórcy tych obiektów w dużej mierze przyczynili się do powstania cywilizacji starożytnego Egiptu. Zabytkom tym poważnie groziło zniszczenie przez wyznawców tak zwanego New Age coraz liczniej przybywających do Nabta Playa w celach kultowych. W ramach akcji ratowniczej kierowanej przez profesora Schilda przeniesiono i zrekonstruowano w Muzeum Nubijskim w Asuanie wspomniany wyżej kalendarz kamienny i siedem pionowych steli.

Profesor Schild w latach po przejściu na emeryturę w dalszym ciągu prowadził badania najstarszych pradziejów w Polsce. Jako uznany autorytet w tej dziedzinie, na zaproszenie młodszych kolegów, udzielał konsultacji i przez wiele sezonów kontynuował prace terenowe paleolitycznego stanowiska w Wilczycach koło Sandomierza (2003-2012) oraz stanowisk torfowych takich jak neolityczne stanowisko w Rzucewie na Pomorzu (1995-2012), mezolityczne i neolityczne stanowisko w Dąbkach na wybrzeżu bałtyckim (2018-2019) i bogate stanowisko z okresu mezolitu w Krzyżu Wielkopolskim (2007-2012). Biorąc czynny udział w tych badaniach, zajmował się zagadnieniami geomorfologii i stratygrafii warstw archeologicznych i przyrodniczych, tak istotnymi w przypadku stanowisk torfowych, co pozwoliło rzucić więcej światła na osadnictwo społeczności łowiecko-zbierackich i neolitycznych Niżu Polskiego, przyczyniając się do szerokiej interpretacji dokonywanych odkryć.

Profesor Schild należy do nielicznych, niestety, badaczy, którzy w całości obszernie opublikowali wyniki swoich badań terenowych. W ogromnej większości prace

${ }^{1}$ Omówienie wcześniejszej działalności Pana Profesora zob.: J.K. Kozłowski, J. Machnik, Kilka słów o Profesorze Romualdzie Schildzie, „Archeologia Polski”, 51/1-2: 2006, s. 7-12; B. Ginter, M. Kobusiewicz, Our Friend, [w:] Man - Millennia - Environment. Studies in honour of Romuald Schild, Z. Sulgostowska, A.J. Tomaszewski red., Warsaw 2008, s. 13-14; Z. Sulgostowska, A.J. Tomaszewski, On the 80 ${ }^{\text {th }}$ birthday of Professor Romuald Schild, „Archaeologia Polona”, 54: 2016, s. 11-13. Zob. także: Złota Ksiega Nauki Polskiej. Naukowcy Zjednoczonej Europy, Gliwice 2006, s. 719 (przypis Redakcji). 
z omawianych lat ogłoszone zostały po angielsku. Kontynuację licznych publikacji powstałych podczas wieloletniej działalności profesora stanowi w tym zakresie dorobek z lat 2008-2021. W latach po przejściu na emeryturę ukazało się dwadzieścia prac własnych lub we współautorstwie dotyczących wczesnej prahistorii północno-wschodniej Afryki oraz siedemnaście publikacji na temat wczesnych pradziejów Europy środkowej. Tu na szczególną uwagę zasługują trzy obszerne monografie: Rydno. Stone Age red ochre quarry and socioeconomic center. A century of research (2011); Wilczyce. A Late Magdalenian winter hunting camp of Central Poland (2014) i Całowanie. A Final Paleolithic and Early Mesolithic site on an island in the ancient Vistula Channel (2014). Wszystkie trzy stanowią monografie kluczowych stanowisk dla znajomości późnego paleolitu i mezolitu Europy środkowej. Do ważnych prac Profesora należy wymienić napisany we współautorstwie obszerny polsko-angielski i angielsko-polski Słownik Archeologii Prehistorycznej (2013), dzieło niezwykle przydatne dla wszystkich archeologów pragnących publikować w obcym języku.

Osiągnięcia profesora Schilda będące wynikiem jego wieloletnich badań ukoronowane zostały w 2020 r. nagrodą Fundacji na rzecz Nauki Polskiej zwaną też często Polskim Noblem.

Z tego, co powyżej powiedziano widać, że profesor Schild swych pierwszych czternastu lat na emeryturze nie zmarnował i wiadomo mi, że dalszej działalności w tym zakresie kończyć nie zamierza.

Michał Kobusiewicz

\section{PROFESSOR ROMUALD SCHILD. CONTINUED RESEARCH IN 2008-2021}

Professor Romuald Schild retired in 2007 after 16 years at the helm of the Institute of Archaeology and Ethnology of the Polish Academy of Sciences. But he did not retire from science and he has engaged actively in scholarship in his field for the past 14 years, ${ }^{1}$ continuing his research on the Paleolithic in two main areas of interest: Northeastern Africa and Central Europe.

Crowning 60 years of prehistoric investigations in Northeastern Africa was a project Schild directed in 2009-2010 to move the stone monuments of the late Neolithic ceremonial center at Nabta Playa in the Western Desert of Egypt to the Nubian Museum in Aswan. In the last few years before retirement Schild had directed the Polish-American Combined Prehistoric Expedition, which had

${ }^{1}$ For a review of Schild's earlier scientific achievement see: J.K. Kozłowski, J. Machnik, Kilka słów o Profesorze Romualdzie Schildzie, "Archeologia Polski”, 51/1-2: 2006, pp. 7-12; B. Ginter, M. Kobusiewicz, Our Friend, [in:] Man - Millennia - Environment. Studies in honour of Romuald Schild, Z. Sulgostowska, A.J. Tomaszewski eds., Warsaw 2008, pp. 13-14; Z. Sulgostowska, A.J. Tomaszewski, On the $80^{\text {th }}$ birthday of Professor Romuald Schild, "Archaeologia Polona", 54: 2016, pp. 11-13. See also: Złota Księga Nauki Polskiej. Naukowcy Zjednoczonej Europy [The Golden Book of Polish Science. The researchers of a United Europe], Gliwice 2006, p. 719 (Note from the Editors). 
explored Nabta Playa for close to half a century. The complex was composed of stone megaliths and vertical stelae oriented toward the magnetic north and the Orion constellation, and included what has come to be called a calendar, that is, an astronomical observatory built of stone boulders. The builders of this complex are certain to have contributed significantly to the emergence of Ancient Egyptian civilization. New Age believers swamping Nabta Paya for cult purposes had threatened the survival of these ancient monuments, prompting a decision to move them to Aswan and reconstruct the calendar and seven vertical stelae in the museum there.

In Poland, Schild continued research on the prehistory of the region, sharing his extensive knowledge with younger colleagues seeking his opinion as an acclaimed expert on many issues. For several seasons he also continued field research at the Paleolithic site of Wilczyce near Sandomierz (2003-2012) and different peat-bog sites like the Neolithic Rzucewo in Pomerania (1995-2012), the Mesolithic and Neolithic Dąbki on the Baltic coast (2018-2019) and the rich Mesolithic complex at Krzyż Wielkopolski (2007-2012). He was interested in the crucial issues of geomorphology and stratigraphy of archaeological and natural strata at peat-bog sites, throwing new light on hunting-gathering communities in the Polish Plain and contributing to a comprehensive interpretation of the discoveries made there.

Schild is also among the lamentably few scholars to publish extensively, and mainly in English, the results of all of his field research. He has added to the long list of publications in the period since his retirement, publishing 20 studies either under his own name or in collaboration with other scholars: on the early prehistory of Northeastern Africa and 17 on the same period in Central Europe. With regard to the latter, one should mention in particular: Rydno. Stone Age red ochre quarry and socioeconomic center. A century of research (2011); Wilczyce. A Late Magdalenian winter hunting camp of Central Poland (2014) and Całowanie. A Final Paleolithic and Early Mesolithic site on an island in the ancient Vistula Channel (2014). All three monographs are of crucial importance for the study of the late Paleolithic and Mesolithic periods in central Europe. Another important achievement is the Professor's Słownik Archeologii Prehistorycznej [Dictionary of Prehistoric Archaeology] (2013), written in collaboration with other authors and highly useful for Polish researchers publishing their work in the congress languages.

Professor Schild's longstanding scholarly achievement was honored in 2020 with the Award of the Foundation for Polish Science, often referred to as the Polish Nobel.

Schild has evidently not squandered these past 14 years in retirement and the present author is privy to the knowledge that the Professor has by no means reached an end of what he still intends to do.

Michat Kobusiewicz

Translated by Iwona Zych 


\section{BIBLIOGRAFIA PRAC PROF. DR. HAB. ROMUALDA SCHILDA ZA LATA $2017-2020^{1}$}

1. (z C h.L. Hille m ) Paleohydrology and paleoenvironments at Bir Sahara: Pleistocene lithostratigraphy and sedimentology in the southern Egyptian Sahara, „Journal of African Earth Sciences", 136, s. 201-215.

2. (z C h.L. Hille m ) Pleistocene deposits in the southern Egyptian Sahara: Lithostratigraphic relationships of sediments and landscape dynamics at Bir Tarfawi, „Studia Quaternaria", 34/1, s. 23-28.

\section{8}

3. (z D. Król) Osadnictwo Cypla Rzucewskiego w świetle stratygrafii wykopów archeologicznych (Prehistoric settlement of the Rzucewo Promontory in the light of the stratigraphy of archaeological cuttings), [w:] Zespół osadniczy z epoki kamienia - Rzucewo, gmina Puck, stanowisko 1, Fontes Commentationesque ad Res Guestas Gedani et Pomeraniae, VII, Gdańsk, s. 40-59.

4. Fred Wendorf, Jr. 31 July 1924 - 15 July 2015. The Founder of the Combined Prehistoric Expedition and for several decades its Guiding Spirit, „Studies in the African Archaeology”, 15, s. 15-26.

2019

5. Uwagi o stratygrafii stanowiska Wojnowo 2 i chronologii jednostek paleolitycznych, mezolitycznych i paraneolitycznych w Regionie Wojnowa, [w:] Region Wojnowo. Arkadia łowców i zbieraczy, M. Kobusiewicz red., Poznań, s. 473-484.

6. (z C h.L. Hill e m, A. B l u s z c z e m ) Age of the Late Middle Paleolithic Nile aggradation: The Khormusan and the Atmur El Kibeish Aterian, [w:] Not just a corridor. Human occupation of the Nile valley and neighbouring regions between 75,000 and 15,000 years ago, A. Leplongeon, M. Goder-Goldberg, D. Pleurdeau red., Paris, s. 71-90.

7. The African chapter in the scientific life of Professor Michat Kobusiewicz, „Archeologia Polona”, 58, s. 9-15.

Bibliografię, na podstawie materiałów dostarczonych przez prof. dr. hab. Romualda Schilda, opracowali Halina Królik i Tomasz Purowski

${ }^{1}$ Niniejszy wykaz stanowi kontynuację bibliografii prac prof. dr. hab. Romualda Schilda (por. T. B o r oń, Z. Sulg o s tow ska, A. J. To m a s z e w sk i, Romuald Schild's bibliography, [w:] Man - Millenia - Environment. Studies in honour of Romuald Schild, Z. Sulgostowska, A.J. Tomaszewski red., Warsaw 2008, s. 15-23; K. Ke r n e d e r - G u b a ła, Bibliography of Romuald Schild - from 2005-2016, „Archaeologia Polona”, 54: 2016, s. 15-19). 
